\title{
Олександра Олійничук,
}

кандидат економічних наук, доцент кафедри економічної безпеки та фінансових розслідувань юридичного факультету

Тернопільського національного економічного університету

\section{Ірина Чайка,}

студентка V курсу юридичного факультету

Тернопільського національного економічного університету

\section{ПРАВОВЕ РЕГУЛЮВАННЯ ПОДАТКОВОГО МЕНЕДЖМЕНТУ В УКРАЇНІ}

\begin{abstract}
Проаналізовано вітчизняний та зарубіжний досвід організачії податкової системи та податкового менеджменту зокрема. Обгрунтовано різновекторність економічних інтересів в управлінні оподаткуванням. Висвітлено структуру податкового законодавства. Розглянуто нормативно-правове забезпечення та еволюиію розвитку податкового менеджменту. Виділено недоліки правової підтримки податкового менеджменту в Україні та сформульовано шляхи удосконалення.
\end{abstract}

Ключові слова: податки, податковий менеджмент, податкове законодавство.

Олийнычук А., Чайка И.

Правовое регулирование налогового менеджмента в Украине

Проанализировано отечественный и зарубежный опыт организации налоговой системы и налогового менеджмента в частности. Обоснованно разновекторность экономических интересов в управлении налогообложением. Освещено структуру налогового законодательства. Рассмотрено нормативно-правовое обеспечение и эволюичю развития налогового менеджмента. Выделено недостатки правовой поддержки налогового менеджмента в Украине и сформулированы пути совершенствования.

Ключевые слова: налоги, налоговый менеджмент, налоговое законодательство.

Oliynychuk O., Chaika I.

Legal regulation of tax management in Ukraine

The domestic and foreign experience of organization of the tax system and tax management in particular are analyzed. The various vectors of economic interests in tax management are substantiated. The structure of tax legislation is highlighted. The legal support and evolution of tax management development are considered. The disadvantages of legal support of tax management in Ukraine are outlined and ways of its improvement are formulated.

Keywords: taxes, tax management, tax legislation.

Актуальність теми. Податки є однією із центральних категорій фінансової науки та практики, оскільки виконують роль дієвого інструмента державного управління процесом розподілу та перерозподілу валового внутрішнього продукту за соціальним, територіальним і галузевим підходами, що дозволяє послабити недоліки ринкових механізмів, нерівномірність розміщення ресурсів і забезпечення суспільними благами, сформувати передумови для стимулювання бізнес-ініціативи, ділової та інвестиційної активності, мотивації до праці, підвищення рівня зайнятості, стабілізації ринкової кон'юнктури [2, с. 23]. Поточний стан підприємництва у вітчизняному просторі вимагає прийняття управлінських рішень в умовах стійких кризових явищ і тривалої невизначеності, коли діяльність підприємств перебуває під суттєвим впливом внутрішніх і зовнішніх загроз, що можуть спричинити неплатоспроможність або й банкрутство суб'єкта господарювання. Важливим напрямом вдосконалення фінансової політики підприємства є впровадження дієвої системи податкового менеджменту. Підприємства потребують розробки та реалізації такої податкової політики, яка б враховувала особливості діяльності суб'єкта господарювання та перспективи його розвитку, а також давала можливість оцінити вплив податкових платежів на його фінансовий стан. Оскільки податки $є$ важливим фактором впливу на рівень економічної безпеки підприємств, то їхнє ефективне функціонування та якісне управління фінансовими ресурсами можливе при розробці належної концепції управління податками.

Аналіз останніх досліджень і публікацій. Питанням податкового менеджменту присвячено багато праць вітчизняних та зарубіжних науковців, зокрема таких, як С. В. Барулін, С. О. Срмакова, Ю. Б. Іванов, Р. Ю. Ісаншина, С. О. Левицька, В. В. Каропова, Л. М. Карпов, А. І. Крисоватий, А. Я. Кізима, В. В. Степаненко,

() Олександра Олійничук, Ірина Чайка, 2019 
А. Ф. Цимбалюк та ін. Водночас недостатня увага приділена дослідженню генезису та поточного стану правового регулювання податкового менеджменту в Україні.

Метою статті $є$ дослідження ретроспективних та сучасних аспектів правового регулювання податкового менеджменту в Україні.

Виклад основного матеріалу. Як свідчить зарубіжний досвід і вітчизняна практика, ефективність впливу податків на всі сфери соціально-економічного життя суспільства залежить насамперед від ефективності управління оподаткуванням, або іншими словами ефективності податкового менеджменту. М. В. Тарасюк відзначає, що податковий менеджмент є видом управлінської діяльності, яка являє собою сукупність знань та наукових поглядів на відносини та сукупність дій органів державної влади (посадових осіб, фізичних осіб) 3 метою виконання цілей та завдань податкової політики [10, с. 4]. Відповідно до нашої позиції під податковим менеджментом пропонується розуміти цілеспрямовану адміністративно-розпорядчу діяльність відповідних структур (органів виконавчої влади - на макро- та мезорівні, а також певних служб бізнес-одиниці - на мікрорівні) щодо оптимізації оподаткування.

Зауважимо, що як окрема галузь знань податковий менеджмент виник на початку 20 ст. і відтоді набув широкого розвитку як наука і практика управління фінансовими ресурсами та відносинами, що охоплює систему принципів, методів, форм і прийомів регулювання ринкового механізму у галузі фінансів 3 допомогою податків. Предметом теорії податкового менеджменту є загальні закономірності виникнення, функціонування і розвитку управління процесом оподаткування, його сутність, особливості суб'єктів та об'єктів управлінської діяльності у вказаній сфері, а також особливості податкових механізмів управлінського впливу.

Податковий менеджмент можна розглядати крізь призму загальнодержавних, регіональних інтересів (які особливо вирізняються в умовах податкової децентралізації останніх років) та індивідуально-підприємницьких економічних інтересів. Останні за своїми сутнісними характеристиками є конроверзійними у порівнянні з двома іншими зазначеними групами. Так, якщо держава загалом та окремий місцевий регіон зацікавлені в максимізації податкових надходжень у державний та місцевий бюджети відповідно задля повного виконання законодавчо делегованих функцій, то господарюючий суб'єкт має антогоністичні пріоритети, використовуючи легальні, а часом і нелегальні методи мінімізації податкового навантаження. Таким чином, означена різновекторність зумовлює доцільність виокремлення державного, регіонального та корпоративного менеджменту, що звісно мають як свою концептуальну єдність, так і суттєві відмінності.

Управління оподаткуванням як важлива сфера науково-практичних досліджень і методичних дій складає частину загальної теорії та практики управління. Це сукупність методів, прийомів і засобів інформаційного забезпечення, за допомогою яких надається функціонуванню податкового механізму заданий законом напрям і координуються податкові дії при суттєвих змінах в економіці та політиці [1, с. 10].

Податковий менеджмент спрямовується не лише на організацію оподаткування, а й на вдосконалення всієї податкової системи. У різних країнах світу податкові системи різняться за певними ознаками, зокрема кількістю податків, видом стягнення, типом побудови, ставками податкових платежів, методикою їхнього розрахунку тощо, водночас всі грунтуються на загальних принципах і одним із ключових є стабільність законодавчої бази. Звісно, вона не може бути сталою впродовж десятиліть, але принципові положення сплати податків слід не змінювати протягом тривалого часу. Наприклад, процес запровадження нових податків та обов'язкових платежів у Великобританії надзвичайно складний і потребує обговорення з громадянами держави - податкоплатниками. Підвищення ставок податків має бути ретельно обгрунтованим і відбуватися тільки за умови виникнення форс-мажорних обставин, коли необхідно збільшити видатки бюджету [2].

У більшості країн світу перед податкоплатниками навіть не виникає питання щодо сплати чи несплати відповідних податків. Їх необхідно сплачувати згідно з чинним законодавством. Аналогічний принцип закладено і у вітчизняному просторі конституційною нормою. Так, відповідно до ст. 67 Конституції України «Кожен зобов'язаний сплачувати податки і збори в порядку і розмірах, встановлених законом» [4]. Тому ключовим аспектом податкового менеджменту є оптимізація податкових платежів певного підприємства відповідно до обставин, що склалися, та умов його діяльності.

У деяких країнах світу закріплені досить високі ставки податкових платежів (значно вищі за ті, що діють нині в Україні). У такому випадку підприємства в цих країнах можуть ставити за мету реєстрацію у вільних економічних (або офшорних) зонах. Наприклад, якщо ставка оподаткування прибутку становить 45\%, то в офшорній зоні вона дорівнює всього 1-2\%. Водночас в різних країнах світу важливе місце посідає принцип рівності всіх платників податків, незважаючи на відомчу підпорядкованість, форми власності, підтримку тих чи інших політичних сил, партій та рухів, регіональну належність тощо. Це ж стосується і надання різних пільг.

Суттєву увагу при розбудові податкових систем у різних країнах світу приділяють розвитку підприємницької діяльності та залученню інвестиційних коштів як вітчизняними, так й іноземними особами. Для 
цього в державі створюють умови для стимулювання цих видів діяльності. У більшості країн значні пільги надають підприємствам-експортерам своєї продукції (при цьому більшість країн укладають між собою угоди про уникнення подвійного оподаткування) [5, с. 70]. На міжнародному рівні порядок обміну інформацією про сплату всіх видів податків між компетентними органами держав-учасниць регламентовано Конвенцією про взаємну адміністративну допомогу в податкових справах 1988 року [3].

Наявність різноманітних варіантів розрахунку та сплати податків, а також різні пільги щодо них дозволяють підприємству при розробці своєї податкової політики розробляти декілька варіантів і обчислити можливу економію. Крім того, ефективна організація податкового менеджменту, розробка податкової політики впливає і на визначення вектора подальшої діяльності підприємства.

Податковий менеджмент грунтується на сформованих податкових правових відносинах, що є системоутворюючою правовою категорією фінансового права. Вони постійно розвиваються та вдосконалюються відповідно до потреб економічного та соціального розвитку держави. Зміна, припинення та реалізація таких правових відносин базується на непорушних фундаментальних засадах, що створюють умови для побудови єдиної системи взаємозв'язків учасників податкових відносин та є важливим орієнтиром тенденцій розвитку податкового законодавства.

Податкове законодавство - сукупність нормативно-правових актів, якими регулюються податкові відносини, регламентується справляння та адміністрування податків, зборів та інших обов'язкових платежів. Принципи податкового законодавства задають основний напрям для конкретизації змісту загального правила у відповідних податкових правових нормах. Тобто можна стверджувати, що податкові правові відносини, які регулюються певними правилами поведінки їх учасників з урахуванням динаміки суспільних процесів в Україні, мають особливі вихідні положення, метою яких є ефективне наповнення публічних грошових фондів. Основними базовими напрямами реалізації податкових правових відносин, які містяться в конкретних податкових правових нормах і потребують законодавчого визначення як спеціальних принципів, є відповідальність держави за формування і реалізацію політики в податковій сфері та відповідальність за виконання прийнятих зобов'язань учасників податкових правовідносин. Ці спеціальні принципи гармонійно поєднуються та забезпечують основні напрями державотворення в Україні.

Структура податкового законодавства відображена на рис. 1.

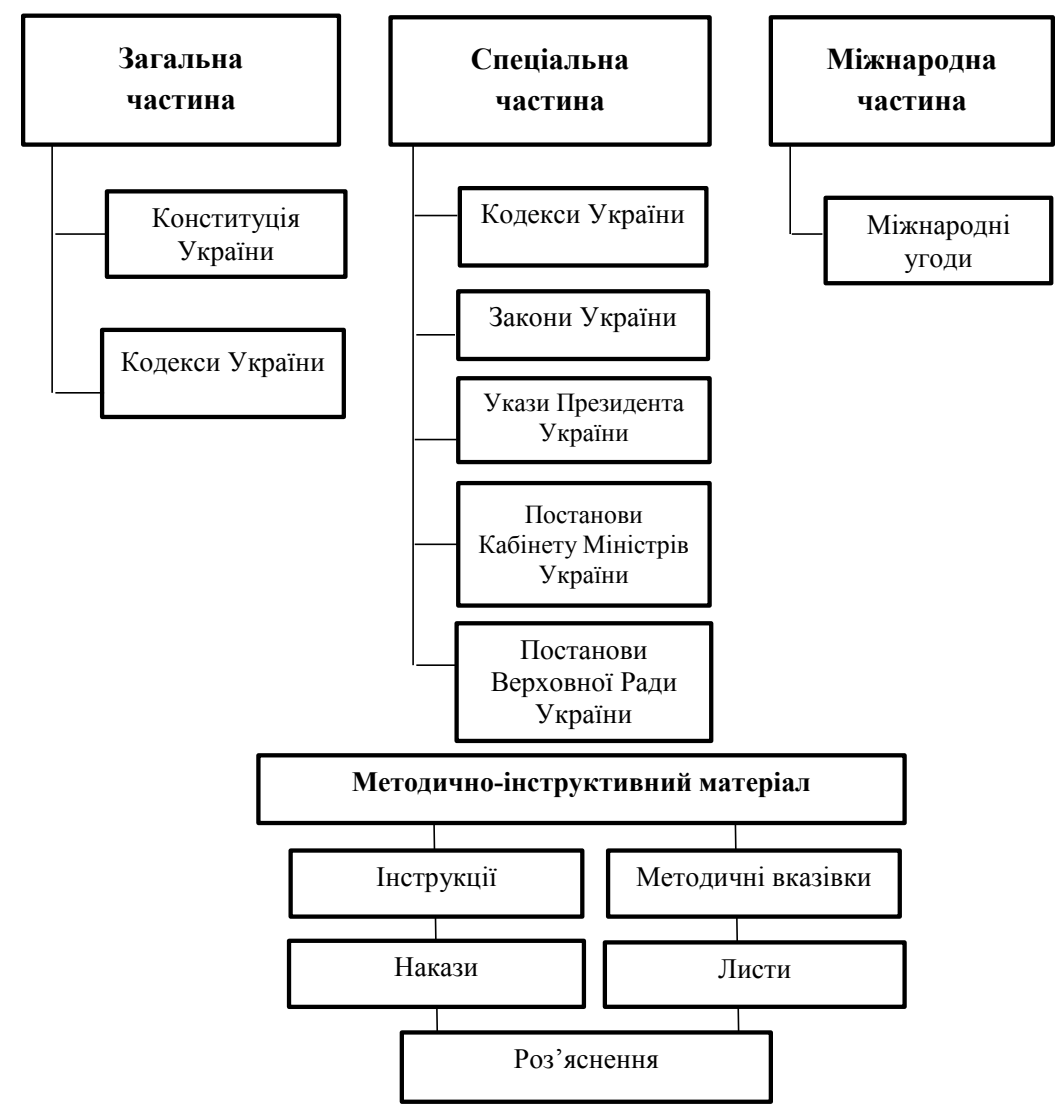

Рис. 1. Структура нормативно-правого забезпечення у сфері оподаткування 
Модель ієрархічної системи нормативно-правових актів податкового менеджменту наведена на рис. 2.

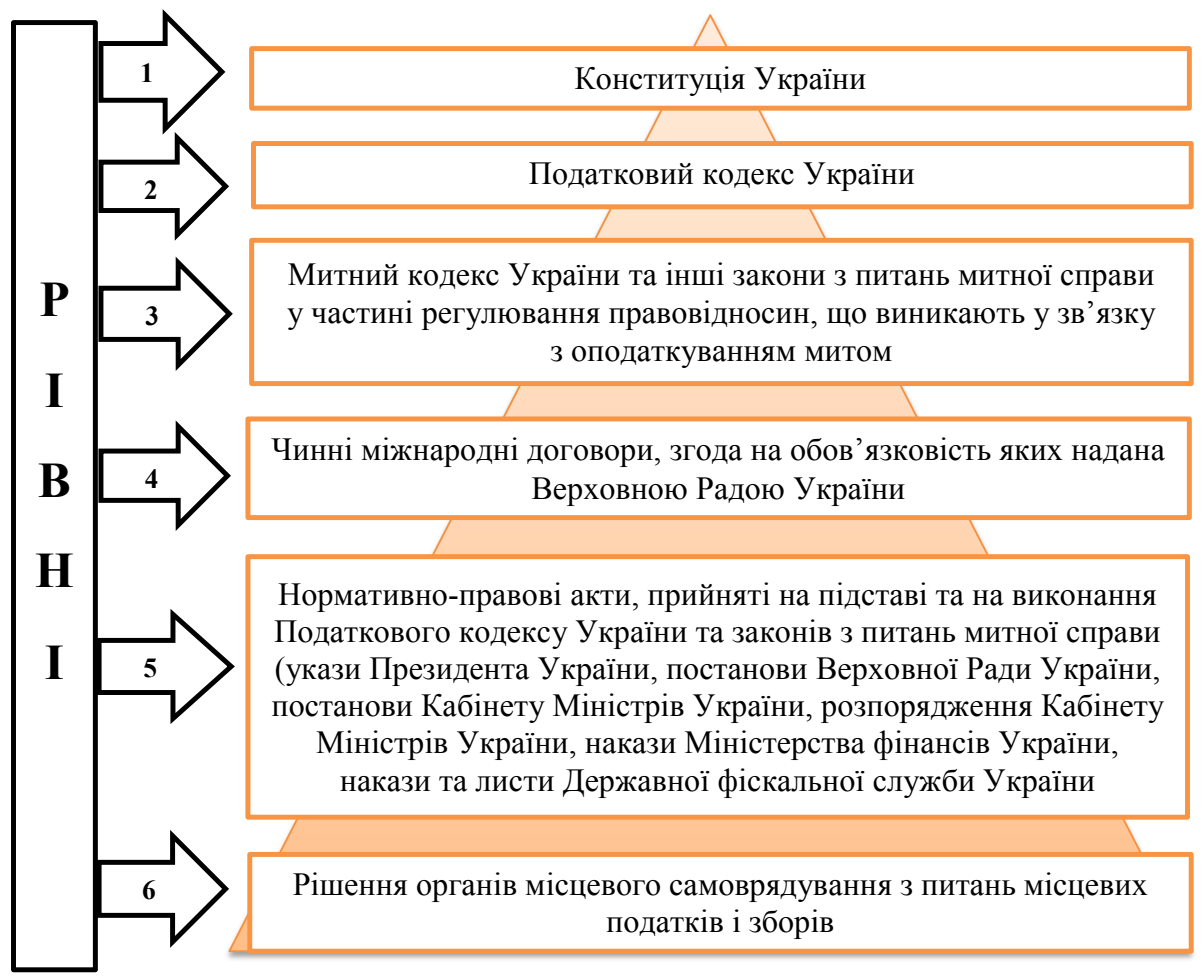

Рис. 2. Нормативно-правовий базис податкового менеджменту [7, с. 18]

Відзначимо, що податковий менеджмент як сфера діяльності в Україні почав розвиватися з 1991 р. на основі Закону України «Про систему оподаткування» від 25.06.1991 р. № 1251-12 [9]. Закон регулював відносини та трактував теоретичні поняття у системі оподаткування. Дуга редакція Закону від 02.02 .1994 р. № 3904-12 показала і врахувала реальний стан податкової системи, який був на той час в Україні. У 1997 р. була прийнята нова редакція з внесеними змінами до закону від 18.02.1997 р. № 77/97, згідно з яким встановлювалися, скасовувалися та вирізнялися податки, збори, призначені для державних і місцевих бюджетів, визначалися внески до державних цільових фондів, а також права, обов'язки і відповідальність платників податків. Наступним кроком в розвитку податкової системи України та податкового менеджменту є прийняття 02.12.2010 р. Податкового кодексу України, який вніс вагомі зміни в розвиток цієї системи [6].

На основі вищезазначеного можна виділити два етапи в еволюції податкового менеджменту:

- перший етап (1991-1995р.) - спрямований на забезпечення максимізації податкових надходжень;

- другий етап (1995 р. і до сьогодні) - поступове зниження податкового тягаря.

До переліку нормативно-правових актів, які регламентують податкові відносини та безпосередньо формують правове підгрунтя податкового менеджменту, слід віднести:

- укази Президента України, зокрема «Про заходи щодо протидії зменшенню податкової бази $\mathrm{i}$ переміщенню прибутків за кордон» від 28.04.2016 р. № 180/2016;

- постанови Верховної Ради України, зокрема «Про вдосконалення діяльності органів доходів і зборів» від 28.02.2014 р. № 838-VII;

- постанови Кабінету Міністрів України, зокрема «Про Державну фіскальну службу України» від 21.05 .2014 р. № 236, «Про утворення територіальних органів Державної фіскальної служби та визнання такими, що втратили чинність, деяких актів Кабінету Міністрів України» від 06.08.2014 р. №311, «Деякі питання електронного адміністрування податку на додану вартість» від 16.10.2014 р. № 569;

- накази Міністерства фінансів України, зокрема «Про затвердження форми податкової декларації про майновий стан і доходи та Інструкції щодо заповнення податкової декларації про майновий стан і доходи» від 02.10.2015 р. № 859, «Про затвердження форми Податкової декларації з податку на прибуток підприємств» від 20.10.2015 р. № 897, «Про затвердження форм та Порядку заповнення і подання податкової звітності з податку на додану вартість» від 28.01.2016 р. № 21;

- накази та листи Державної фіскальної служби України. 
Водночас варто наголосити про наявність недоліків правової підтримки податкового менеджменту в Україні, які призводять до значних прорахунків при визначенні мети і планування заходів 3 реалізації податкової політики держави, зокрема:

1) нестабільність податкового законодавства;

2) наявність суперечностей між окремими нормами Податкового кодексу України та підзаконними нормативно-правовими актами, які повинні узгоджуватися з положеннями Кодексу. Інколи це призводить до необгрунтованого збільшення податкового навантаження на платників податків, створюючи передумови для ухилень від сплати податків, звернення до інституту оптимізації їх сплати;

3) наявність розгалуженої системи податкових пільг;

4) послаблення дії мотиваційного механізму державного управління діяльністю органів доходів і зборів тощо.

Для мінімізації такого впливу потрібні час і комплексні зусилля всіх суб’єктів управління оподаткуванням в Україні.

Висновки. Отже, можна зробити висновок, що подальше реформування податкової системи України, його наукове супроводження доцільно здійснювати з урахуванням багатоаспектності такого управлінського явища, як податковий менеджмент. Модернізуючи практику оподаткування, слід брати до уваги, що досконалий податковий менеджмент, тяжіючи до принципів державного управління, здатен суттєво сприяти формуванню в Україні привабливого бізнес-клімату.

Правове регулювання у сфері оподаткування в Україні слід спрямовувати на створення оптимальної моделі поведінки учасників податкових правових відносин, що базується першочергово на конституційних принципах, які становлять основу розвитку принципів права, у тому числі й принципів податкових правових відносин.

Організація ефективного податкового менеджменту характеризує результативність реалізації податкової політики та діяльності його суб'єктів. В Україні питання підвищення ефективності податкового менеджменту сьогодні є одним 3 найактуальніших суспільних завдань, оскільки завдяки легальному зменшенню податкового тягаря можна спрямувати вивільнені кошти на розширений розвиток діяльності підприємства. А тому дослідження аспектів організації податкового менеджменту на підприємстві $є$ перспективами подальших наукових досліджень у цьому напрямі.

\section{Список використаних джерел}

1. Башняк О. С. Принц̧ипи оподаткування та їх реалізація у податковому законодавстві України : автореф. дис. на здобуття наук. ступеня канд. юрид. наук : спеи. 12.00.07-теорія управління; адміністративне право і процес; фінансове право; інформаційне право / О. С. Башняк. - Харків : Начіональна юридична академія Украӥни ім. Ярослава Мудрого, 2005. - 20 с.

2. ванов Ю. Б. Податковий менеджмент : підруч. / Ю. Б. Іванов, А. І. Крисоватий, А. Я. Кізима, В. В. Карпова. - К. : Знання, 2008. - 525 c.

3. Конвенція про взаємну адміністративну допомогу в податкових справах (ЕTS 127) від 25 січня 1988 р. [Електронний ресурс]. - Режим доступу : https://zakon.rada.gov.ua/laws/show/994_325.

4. Конституиія України від 28.06.1996 № 254к/96-ВР [Електронний ресурс]. - Режим доступу : http:// zakon4.rada.gov.ua/laws/show $/ 254 \%$ D0\%BA/96-\%D0\%B2\%D1\%80.

5. Левицька С. О. Податковий менеджмент на макрорівні: вітчизняна та міжнародна практики впровадження : наук. записки Національного ун-ту «Острозька академія» / С. О. Левицька, А. Ф. Цимбалюк. 2011. - Вип. 16. - С. 69-76. - (Сер. «Економіка»).

6. Податковий кодекс України від 02.12.2010 № 2755-VI. [Електронний ресурс]. - Режсим доступу : httр:// zakon2.rada.gov.ua/laws/show/2755-17.

7. Податковий менеджмент : навч. посіб. / О. О. Клокар, С. В. Бойко, І. Г. Кеменям, Н. М. Рущишин. Львів : СПОЛОМ, 2017. - 320 c.

8. Про Державну фіскальну службу України : Положення, затверджене постановою Кабінету Міністрів Украӥни від 21.05.2014 p. № 231. [Електронний ресурс]. - Режим доступу : http://zakon5.rada. gov.ua/laws/show/236-2014-\%D0\%BF.

9. Про систему оподаткування : Закон України від 25.06.1991 р. № 1251-ХII (втратив чинність від 01.01.2011). [Електронний ресурс]. - Режим доступу : https://zakon.rada.gov.ua/laws/show/1251-12.

10. Тарасюк М. В. Теоретичні засади державного податкового менеджменту / М. В. Тарасюк // Сталий розвиток економіки. - 2013. - № 3. - C. 3-8. 


\section{References}

1. Bashniak, O.S. (2005). Pryntsypy opodatkuvannia ta yikh realizatsiia u podatkovomu zakonodavstvi Ukrainy [Principles of taxation and their implementation in the tax legislation of Ukraine]. Extended abstract of candidate's thesis. Kharkiv: Yaroslav Mudryi National Law University [in Ukrainian].

2. Ivanov, Yu.B., Krysovatyi, A.I., Kizyma, A.Ia., Karpova, V.V. (2008). Podatkovyi menedzhment [Tax management]. Kyiv: Znannia [in Ukrainian].

3. Konventsiia pro vzaiemnu administratyvnu dopomohu v podatkovykh spravakh (ETS 127) (1988), [Convention on Mutual Administrative Assistance in Tax Matters]. https://zakon.rada.gov.ua Retrieved from https://zakon. rada.gov.ua/laws/show/994_325 [in Ukrainian].

4. Konstytutsiia Ukrainy, pryiniata 28 cher. 1996 roku, [Constitution of Ukraine from June 28 1996], http://zakon4.rada. gov.ua Retrieved from http://zakon4.rada.gov.ua/laws/show/254\%D0\%BA/96-\%D0\%B2\%D1\%80 [in Ukrainian].

5. Levytska, S.O., Tsymbaliuk, A. F. (2011). Podatkovyi menedzhment na makrorivni: vitchyzniana ta mizhnarodna praktyky vprovadzhennia [Tax management at the macro level: national and international implementation practices]. Naukovi zapysky [Natsionalnoho universytetu «Ostrozka akademiia»]. Ser. : Ekonomika. - The National University of Ostroh Academy Proceedings. Ser.: Economy, 16, 69-76 [in Ukrainian].

6. Podatkovyi kodeks Ukrainy [Tax Code of Ukraine]. (2010, December 2), http://zakon4.rada.gov.ua Retrieved from http://zakon4.rada.gov.ua/laws/show/2755-17 [in Ukrainian].

7. Klokar, O.O., Boiko, S.V., Kemeniash, I.H., Rushchyshyn, N.M. (2017). Podatkovyi menedzhment [Tax management]. Lviv: SPOLOM [in Ukrainian].

8. Polozhennia Pro Derzhavnu fiskalnu sluzhbu Ukrainy, zatverdzhene postanovoiu Kabinetu Ministriv Ukrainy : pryiniatyi 21 trav. 2014 roku № 231 [Position of Cabinet of Ministers of Ukraine from May 21 2014, №231], http:// zakon5.rada.gov.ua Retrieved from http://zakon5.rada.gov.ua/laws/show/236-2014-\%D0\%BF [in Ukrainian].

9. Zakon Ukrainy «Pro systemu opodatkuvannia» : pryiniatyi 25 cher. 1991 roku № 1251-XII [Law of Ukraine «On taxation system» from June 25 1991, № № 1251-XII], https://zakon.rada.gov.ua Retrieved from https:// zakon.rada.gov.ua/laws/show/1251-12. [in Ukrainian].

10. Tarasiuk, M. V. (2013). Teoretychni zasady derzhavnoho podatkovoho menedzhmentu [Theoretical foundations of state tax management]. Stalyi rozvytok ekonomiky - Sustainable development of the economy, 3, 3-8 [in Ukrainian].

Стаття надійшла до редакції 30.01.2019. 